\title{
PHARMACOKINETIC CHARACTERISTICS OF A NIFEDIPINE AND LIDOCAINE FIXED COMBINATION IN THE FORM OF RECTAL CREAM: TWO DECADES DATA ANALYSIS
}

\author{
R. Ottaiano ${ }^{1}$, M. Sebastiano ${ }^{1}$, L.B. Bondarenko ${ }^{2 *}$, O.V. ludina ${ }^{3}$ \\ ${ }^{1}$ New.Fa.Dem., S.r.l., Giugliano in Campania, Italy \\ ${ }^{2}$ Institute of Pharmacology \& Toxicology of NAMS of Ukraine, SI, Kyiv, Ukraine \\ ${ }^{3}$ UA PRO-PHARMA, LLC, Kyiv, Ukraine \\ *Corresponding author: larabon04@yahoo.com
}

Received 26 February 2021; Accepted 25 March 2021

\begin{abstract}
The creation of medicines' fixed combinations from compounds with complementary effects is one of the most popular directions in modern pharmacology and pharmaceutics. In case of nifedipine and lidocaine fixed combination such approach is quite obvious. The present review article is devoted to the analysis of clinical and non-clinical studies results on the assessment of the pharmacokinetic characteristics of these medicines. Although the oral route is the most convenient for drug administration, there are a number of circumstances where this is not possible from either a clinical or pharmaceutical perspective. In these cases, the rectal route may represent a practical alternative and can be used to administer drugs for both local and systemic actions. Research data of last decades suggested that nifedipine, a calcium channel blocker, could be effective in reducing anal resting pressure and in healing chronic anal fissure and acute thrombosed hemorrhoids. Another component of fixed combination lidocaine is a local anesthetic usually used to relieve pain of anal fissures and symptomatic hemorrhoids. In combinations lidocaine and nifedipine have complementary actions. Analysis of all available studies (during last 2 decades) which were aimed to investigate pharmacokinetic characteristics of a nifedipine and lidocaine fixed combination in the form of rectal cream showed that following topical application, the active ingredients nifedipine and lidocaine are absorbed into the bloodstream in only small quantities that have no major implications for the safety of the product, and systemic absorption, if any, was incomparably lower than absorption following per os administration of the two active ingredients.
\end{abstract}

Keywords: nifedipine; lidocaine; fixed combination; pharmacokinetic characteristics.

\section{Introduction}

Although the oral route is the most convenient for drug administration, there are a number of circumstances where this is not possible from either a clinical or pharmaceutical perspective. In these cases, the rectal route may represent a practical alternative and can be used to administer drugs for both local and systemic actions [1]. The environment in the rectum is considered relatively constant and stable and has low enzymatic activity in comparison to other sections of the gastrointestinal tract. In addition, drugs can partially bypass the liver following systemic absorption, which reduces the hepatic first-pass effect. Therefore, rectal drug delivery can provide significant local and systemic levels for various drugs, despite the relatively small surface area of the rectal mucosa. Further development and optimization of rectal drug formulations have led to improvements in drug bioavailability, formulation retention, and drug release kinetics [2-4].
The creation of medicines' fixed combinations from compounds with complementary effects is one of the most popular directions in modern pharmacology and pharmaceutics. In case of nifedipine and lidocaine fixed combination such approach was quite obvious [5].

It should be noted that the pharmacokinetic profile of finished dosage forms for topical use is an important characteristic from a regulatory point of view. The level of systemic adsorption and other pharmacokinetic parameters directly affect the format and content of pre-marketing studies of pharmaceutical products [6-9].

The present review article is devoted to the analysis of clinical and non-clinical studies results on the assessment of the pharmacokinetic characteristics of these medicines.

\section{Nifedipine and lidocaine fixed combination: rectal drug delivery}

Compounded topical calcium channel blockers are used for the treatment of wounds, such as 
anal fissures and diabetic ulcers [10]. Among them diltiazem and nifedipine are the calcium channel blockers with the most evidence for topical use. They are compounded extemporaneously with cream, gel, and ointment bases. Oral and topical calcium channel blockers had been shown to lower anal resting pressure by relaxing the internal anal sphincter [11]. Calcium and its entry through the L-type calcium channels are important for the maintenance of the internal anal sphincter tone [12, 13]. Research data of last decades suggested that nifedipine, a calcium channel blocker, could be effective in reducing anal resting pressure [14] and in healing chronic anal fissure and acute thrombosed hemorrhoids [15-17].

But taking into account the obvious advantages of using calcium blockers, it is necessary to simultaneously focus on the fact that these positive features apply only to their superficial application, which excludes the profound systemic effect observed with oral administration. In this case, the ability to cross a barrier, such as skin and rectal mucosa, can modify the effect that the drug have when taken by oral delivery. It allows to avoid first-pass hepatic metabolism (metabolism occurring when drug is taken up from the gastrointestinal (GI) tract and delivered to the liver by portal blood flow), with simultaneous localization of action, etc.

It must be noted that the oral administration of calcium antagonists is associated with serious side effects such as hypotension and flushing, which may decrease the patient's compliance with the treatment [18].

On the contrary topical diltiazem and nifedipine were highly effective, achieving a healing rate of $67 \%$ for diltiazem and up to $95 \%$ for nifedipine [19]. Comparison of the efficacy of calcium channel blockers with glyceryl trinitrate in the treatment of anal fissure showed that the treatment with nifedipine achieved high healing rates (89\%) comparable to those previously reported $(95 \%)$ [19]. The incidence of adverse effects with nifedipine was much lower than with glyceryl trinitrate (5\% vs. $40 \%$ ) and comparable to those reported with topical but not oral calcium channel blockers $[11,19]$. The recurrence rate with nifedipine was similar to the glyceryl trinitrate. Thus, nifedipine applied topically for management of chronic anal fissure was more effective and had fewer side effects than topical glyceryl trinitrate. The recurrence rate was high with both medications.

Another component of fixed combination lidocaine is a local anesthetic usually used to relieve pain of anal fissures and symptomatic hemorrhoids $[20,21]$. In combinations lidocaine and nifedipine have complementary actions. Calcium channel blockade caused by nifedipine stipulated relaxation of anal sphincter smooth muscle, thus weakening the pain after hemorrhoidectomy [22, 23], which had been confirmed in clinical trials. The results of clinical trials in patients with anal fissures and hemorrhoidal thrombosis demonstrated that such fixed combination was safe and effective for anorectal application [24, 25], giving rise to only negligible adverse effects [25].

Based on these findings, a topical formulation containing $0.3 \%$ nifedipine and $1.5 \%$ lidocaine (lignocaine) [Antrolin ${ }^{\circledR}$, Bracco SpA, Milan, Italy] had been proposed for application to the anal verge as a means of reducing haemorrhoidectomy pain and its pharmacokinetic was investigated [26].

Previous in vitro tests showed that nifedipine in this formulation relaxed anal sphincter smooth muscle [21, 22], thereby targeting a cause of pain after haemorrhoidectomy, and the results of clinical trials in patients with anal fissures and haemorrhoidal thrombosis showed that nifedipine and lidocaine ointment was safe and effective following anorectal application [23, 24]. However, these clinical trials did not investigate the systemic absorption of the active agents.

Topical application of the ointment to healthy volunteers had been shown not to produce therapeutically significant serum concentrations of the active ingredients and/or their active metabolites [27], but there were no data on the systemic absorption profiles of nifedipine and lidocaine when this two agents were applied simultaneously to the anal verge of patients with inflamed or injured anal mucosa. It was important to establish that neither of this two active ingredients in the mixture could promote the passage of the other into the circulation, producing blood concentrations that were able to generate detectable systemic effects [28-33].

Therefore, phase IV clinical trial was held [26] which aim was to assess the pharmacokinetic profile and the safety of an ointment containing nifedipine and lidocaine applied anorectally to patients undergoing Milligan-Morgan haemorrhoidectomy by:

(i) monioring the serum concentrations of the active ingredients after a single application;

(ii) monitoring changes in haemodynamic status that could be related to systemic absorption of the active ingredients;

(iii) documenting any other adverse effects that could be related to either or both of the active ingredients. 
Inclusion criteria were males and females aged 18-80 years with third or fourth degree haemorrhoids according to the American Society of Colon \& Rectum Surgery (ASCRS) classification who were undergoing Milligan-Morgan haemorrhoidectomy with subarachnoid spinal anaesthesia, without anal sphincter dilatation or sphincterotomy.

Exclusion criteria were: caine;

(i) ongoing treatment with nifedipine or lido-

(ii) pregnancy or lactation;

(iii) allergy to nifedipine or lidocaine;

(iv) associated local disorders that were to be treated surgically (abscess, tumour, fistula, anal fissure);

(v) poor general condition such as American Society of Anaesthesiologists (ASA) classification 4 or 5 .

At baseline, all subjects underwent clinical assessment (including heart rate and BP measurements), laboratory investigations (including serum chemistry tests, complete blood count and measurement of prothrombin time), ECG, chest X-ray, flexible sigmoidoscopy and local clinical examination (including inspection, rectal examination and anoscopy).

Neither nifedipine nor lidocaine (or other drugs known to interfere with their bioavailability) were administered at least 1 week before surgery. All patients refrained from smoking and drinking alcoholic and caffeine-containing beverages for 12 hours before and during the study. During the postoperative phase the patient could receive any drug that did not interact in any way with the determination of nifedipine or lidocaine concentrations.

The pharmacokinetic analyses of nifedipine and lidocaine were carried out with use of the ointment, which contained nifedipine $(0.3 \% \mathrm{w} / \mathrm{w})$ and lidocaine $(1.5 \% \mathrm{w} / \mathrm{w})$ as active ingredients. All other ingredients in the ointment were excipients currently used for formulation of haemorrhoidal ointments:

white petrolatum,

propylene glycol,

polyethylene glycol,

cetearyl alcohol,

glyceryl stearate,

water,

methyl and propyl p-hydroxybenzoates.

The investigational product was applied circumferentially $1 \mathrm{~cm}$ inside the anus at the internal anal sphincter with a gentle massage lasting at least 5 minutes to allow uniform product distribution by healthcare staff soon after the surgical procedure.
Surgical procedures were performed in an average mean - SD time of $32.16-7.22$ minutes (range 18-45 minutes).

The study was planned as a single-dose study with determination of nifedipine and lidocaine in serum after administration of a single dose of $3 \mathrm{~g}$ of a topical formulation (nifedipine and lidocaine ointment). Blood samples were collected in Vacutest $^{\circledR}$ tubes (Becton Dickinson, Franklin Lakes, NJ, USA) from the antecubital vein of each patient (5 mL each sample) at 0 (baseline before surgery) and $20,40,60,90,120,240,360,480$ and 720 minutes after surgery. The frequency and timing of the timepoints were determined on the basis of the half-lives of this two active ingredients after systemic administration [28-36]. The samples collected at 0 minutes were considered as blanks and used to confirm the assignment of peak identities to nifedipine, its metabolites and lidocaine, as well as to verify their recovery, the absence of interfering peaks and the accuracy of the method.

Determination of nifedipine concentrations was carried out using an HPLC method previously validated for precision, accuracy, linearity, specificity and recovery [27]. The analytical method permits measurement of nifedipine in nanograms. The intra- and interday precision of the nifedipine calibration standards, a measure of the degree of repeatability of the assay under normal operating conditions expressed as the coefficient of variation of the concentrations calculated for the standard reference curves within a single day and between different days, was $<20 \%$. The accuracy of the quality control samples was $102.94 \%$ for calibration curves. The mean absolute recovery of nifedipine from serum was $>80 \%$. The limit of quantification (LOQ) for nifedipine was $5 \mathrm{ng} / \mathrm{mL}$. The limit of detection (LOD) was $3 \mathrm{ng} / \mathrm{mL}$.

A similar HPLC assay method for quantification of lidocaine and its metabolites monoethyl glycinexylidide (MEGX) and glycinexylidide (GX) was validated. The intra- and interday precision of lidocaine calibration standards, a measure of the degree of repeatability of the assay under normal operating conditions expressed as the coefficient of variation of the concentrations calculated for the standard reference curves within a single day and between different days, was $<20 \%$. The accuracy of the quality control samples, determined by comparing the mean calculated concentration with the spiked target concentrations of the quality control samples, was $105 \%$. The mean absolute recovery of lidocaine from serum was $>85 \%$. LOQ was $10 \mathrm{ng} / \mathrm{mL}$ and LOD was $5 \mathrm{ng} / \mathrm{mL}$. 
Both methods were able to detect serum levels much lower than known therapeutic windows for nifedipine $(47-20 \mathrm{mg} / \mathrm{mL})$ and lidocaine (1.5$6 \mathrm{mg} / \mathrm{mL}$ ) [37].

Determination of nifedipine and lidocaine serum concentrations and noncompartmental pharmacokinetic parameters were calculated by standard methods: nifedipine and lidocaine maximum concentrations $\left(C_{\max }\right)$ were taken as the maximum observed concentrations in serum, and the time to reach $C_{\max }\left(t_{\max }\right)$ was taken as the sampling time when $C_{\max }$ was observed; the area under the serum concentration-time curve from 0 (time of dosing) to 12 hours $\left(\mathrm{AUC}_{12}\right)$, or to the last sampling time that corresponds to a quantifiable concentration (from 0 to 6 hours $\left[\mathrm{AUC}_{6}\right]$ ), was calculated using the linear trapezoidal rule.

Heart rate and blood pressure (systolic and diastolic) were checked in clinostatism at baseline at all sampling times after dosing.

The safety analysis included the course of signs and symptoms elicited by questionnaire assessed at baseline and at all time points. Signs and symptoms and any other kind of adverse event that occurred during the first 24 hours were reported. A standard 12-lead ECG was performed at baseline and 720 minutes after application of the ointment.

Twenty-four patients were recruited (17 males and 7 females) aged 23-71 years (mean - SD: 42.9-4.9 years). Most patients had grade III haemorrhoids $(n=18[75 \%])$; the remaining patients had grade IV lesions $(n=6$ [25\%]). The haemorrhoids were always associated with hyperaemia of the anorectal mucosa and with inflammation in 22 of 24 patients. The patients were all in good general health (ASA $1=19$, ASA $2=4$ ), with one patient classified as ASA 3 (i.e. presence of severe systemic disease that was not incapacitating). None of the patients had any history or evidence of serious illness.

The HPLC method established for the study resulted in good detectability and quantification of nifedipine and lidocaine in serum with minimal interference from biological components. The presence of either nifedipine or lidocaine and metabolites in serum before application of the investigational product was excluded by comparison with the same samples spiked with the respective pure compounds. No signal interfering with signals for nifedipine and its metabolites nor for lidocaine and its metabolites was observed in the chromatograms of the serum samples collected at time 0 from 24 patients.
It was demonstrated that the serum concentrations of nifedipine were very low and did not permit the calculation of any pharmacokinetic parameters of either nifedipine or its metabolites. A few samples were quantifiable for nifedipine content in only five patients $(20.8 \%)$, in whom concentrations ranged from $5.9 \mathrm{ng} / \mathrm{mL} 20$ minutes after application $\left(T_{20}\right)$ to $18.8 \mathrm{ng} / \mathrm{mL} 120$ minutes after application $\left(T_{120}\right)$. No detectable signal for nifedipine was found, at any collection time, in the serum samples of the other 19 patients. From $T_{120}$ to $T_{240}$, only one patient had very low signals for concentrations of nifedipine. Further determinations of nifedipine at $T_{480}$ and $T_{720}$ post-dose were therefore not carried out.

Unlike nifedipine concentrations, lidocaine concentrations were detectable in all patients. Thus, it was possible to calculate pharmacokinetic parameters for lidocaine, albeit with one change $\left(\mathrm{AUC}_{6}\right.$ instead of $\left.\mathrm{AUC}_{12}\right)$ and one omission, namely the drug's half-life.

Only non-significant variations in heart rate and in both mean systolic blood pressure and mean diastolic blood pressure were observed after a single dose of $3 \mathrm{~g}$ of study ointment: lower values of mean systolic and diastolic blood pressure were observed at $T_{90}$ and $T_{360}(p>0.1$ and $p>0.35 ; p=0.1$ and $p>0.05$, respectively). Similarly, a slight but nonsignificant decrease in mean heart rate was observed at $T_{60}(p>0.05)$ and $T_{360}(p>0.05)$. No correlation with nifedipine concentrations was possible because of the limited values available.

No significant drug-related adverse effects were reported by any subjects following application of the drug combination. Routine laboratory tests revealed no notable changes. No signs or symptoms requiring monitoring were identified.

This study showed that following a single application of nifedipine and lidocaine ointment in a population of patients undergoing open haemorrhoidectomy, absorption of nifedipine was negligible and absorption of lidocaine resulted in serum concentrations below therapeutic levels.

However, it is important to remember that in this study no more than $9 \mathrm{mg}$ of nifedipine and no more than $45 \mathrm{mg}$ of lidocaine were administered in each dose $(3 \mathrm{~g})$ of ointment. At such dosages, any possible systemic absorption would be expected to produce serum concentrations at a lower level than those observed during oral intake, as previously reported in patients with cirrhosis and in healthy volunteers administered with a single-dose nifedipine $10 \mathrm{mg}$ capsule (Adalat ${ }^{\circledR}$, Bayer AG, Leverkusen, 
Germany) and $50 \mathrm{mg}$ of lidocaine solution (Xylocaine $^{\circledR}$, Astra Chemicals, Sweden) [30].

The serum concentrations of nifedipine after anorectal application of the tested product did not permit the calculation of any pharmacokinetic parameters. A few samples were quantifiable for nifedipine content in only five patients $(20.8 \%)$. The concentrations ranged from 5.9 to $18.8 \mathrm{ng} / \mathrm{mL}$, and were always lower not only than the maximum concentrations achieved with the immediate-release formulation of nifedipine (Adalat ${ }^{\circledR} 10 \mathrm{mg}$ capsules, $C_{\max } 65-100 \mathrm{ng} / \mathrm{mL}$ ), but also than the maximum concentration achieved with the slow-release formulation of nifedipine (Adalat Crono ${ }^{\circledR} 30 \mathrm{mg}$ tablets, Cmax 20-21 ng/mL), both of these being marketed products approved for long-term therapeutic use. For these reasons, further investigations into the pharmacokinetic parameters of the nifedipine formulation were stopped.

Although this single-dose study demonstrated that nifedipine was poorly absorbed into the bloodstream and only five patients had measurable concentrations of the drug, it also clearly showed, in contrast, that lidocaine can be quantitatively absorbed and produces relatively higher serum concentrations, reaching $>1 \mathrm{mg} / \mathrm{mL}$ in three patients, and being detectable in all patients. The mean lidocaine concentration was similar to that reported $(221-80 \mathrm{ng} / \mathrm{mL})$ for a marketed $2.5 \%$ lidocaine and 2.5\% prilocaine cream, applied to the oral mucosa, which has been approved for therapeutic use and proposed for relief of pain after haemorrhoidectomy $\left(\right.$ EMLA $^{\circledR}$, Astra-Zeneca, Macclesfield, UK) [38, 39].

Individual values for lidocaine varied considerably in the current study. Only three patients had maximum concentrations above $1000 \mathrm{ng} / \mathrm{mL}$ (1037.8 ng/mL, patient 1; $1044.75 \mathrm{ng} / \mathrm{mL}$, patient 14; and $1364.1 \mathrm{ng} / \mathrm{mL}$, patient 23). These outlier concentrations were four to five times lower than the threshold of CNS lidocaine toxicity (5000$6000 \mathrm{ng} / \mathrm{mL}$ ) and lower than the highest maximum serum concentrations following intercostal nerve block, approximately $1.5 \mathrm{mg} / \mathrm{mL}$ [32, 33, 37-39]. Since lidocaine may penetrate freely into the blood circulation via injured anal mucosa and this penetration varies and depends on the severity of the damage to tissues and blood vessels, the data obtained in the present study, which were drawn from a single-dose application, cannot be used to evaluate the risk in patients applying the drug twice daily for 2 weeks.

There are a number of reports in the literature showing widespread safe use of topical lidocaine at anal diseases at higher doses and with longer dura- tion of treatment [40-43], but further studies evaluating lidocaine concentrations in serum using multiple-dose regimens are still required.

The findings of the abovementioned pharmacocinetics study [26] may also support conclusions from previous study of the same authors indicating that anorectal application of nifedipine and lidocaine does not produce therapeutically significant serum concentrations of the active ingredients and/or their active metabolites in healthy volunteers [27]. In that study, 12 adult healthy volunteers applied the product topically twice daily for 7 days. Blood samples were drawn 0, 30, 60, 240, 480 and 720 minutes after the first application (single dose) and 1 and 7 days after treatment (multiple doses) to detect nifedipine and lidocaine in serum by HPLC. Traces only of a nifedipine metabolite were detected in three subjects $30 \mathrm{mi}$ nutes after application, 7 days after treatment, and 30 minutes and 4 hours after the first application, respectively; traces of lidocaine were also detected in the latter subject.

A major point of criticism of the results of this study [27] might have been that the anal mucosa of healthy volunteers was intact, whereas in the proposed indications - anal fissure or thrombosed haemorrhoids - it was not.

Such a presence of clinical pharmacokinetic studies not only on healthy volunteers, but also on patients is absolutely necessary. These both pharmacokinetic studies [26, 27] should therefore be considered very useful, because the lack of absorption of the active ingredients of nifedipine and lidocaine in healthy volunteers does not rule out absorption in patients, in whom topical absorption of the active ingredients may be higher because of lesions produced in the anorectal mucosa by the inflammatory process that occurs in anal fissure, haemorrhoids or haemorrhoidectomy. It should be remembered that an inflammatory infiltrate is usually present in chronic anal fissures and is associated with continuous hypertonicity of the internal sphincter, microcirculatory disturbance and presence of fibrosis and myositis throughout the internal anal sphincter [44].

Moreover, additional experiment that utilized microdialysis in the dermis to obtain real-time dermal pharmacokinetic parameters in healthy volunteers demonstrated a 50 -fold increase and differentiated cutaneous penetration of a drugs in the barrier-perturbed skin of severe dermatitis, compared with non-inflamed skin [45]. The degree of drug penetration was shown to correlate with noninvasive quantification of barrier damage. 
Previous randomized clinical trials involving patients with anal fissures or thrombosed haemorrhoids who were treated with nifedipine or nifedipine/lidocaine ointment did not investigate the systemic absorption of the active ingredients [23, 24, 46]. However, these studies found that systemic adverse effects after ointment administration were insignificant, and postural hypotension did not occur as a result of systemic absorption. Nevertheless, further research focusing on the pharmacokinetics of the two drugs in patients with anal fissures and haemorrhoidal thrombosis is still warranted.

The investigation in patients who had undergone haemorrhoidectomy [26] (a condition in which inflamed and damaged tissues may improve absorption of the active ingredients) was supposed to demonstrate increased levels of systemic adsorption of nifedipine/lidocaine. Haemorrhoidectomy may not represent an ideal model for damaged and inflamed mucosa because the haemorrhoidal pile is excised together with mucosa and perianal skin during the Milligan-Morgan operation. Thus, the residual wound is more extensive but may not be comparable with the mucosal changes that are observed in patients with chronic anal fissures and haemorrhoidal thrombosis. Nevertheless, postoperative pain remains the major drawback of excisional haemorrhoidectomy [47] and research into novel methods for the control of pain after haemorrhoidectomy is required.

As expected, pharmacokinetic evaluation showed that systemic absorption occurred to a greater extent in this study [26] than in the study of healthy volunteers [27], but still in only small amounts. Therefore, the ointment appeard to act in the main locally on the internal anal sphincter, with very limited detectable systemic absorption. Neither of the two active ingredients in the mixture seemed to promote the passage of the other into the circulation, thereby producing blood concentrations that were able to generate detectable systemic effects [28-33]. Even in the patients who absorbed the active ingredients to the greatest extent, serum concentrations never exceeded the Cmax recorded after administration of the oral formulations approved for chronic therapeutic use [37].

The low absorption of the active ingredients resulted in excellent tolerability, as no important changes in vital signs and no adverse events of any other kind were reported. In addition, since there were no significant variations in haemodynamic parameters, and only traces of serum concentrations of nifedipine could be determined within the limits of the method used, this study was also una- ble to establish any correlation between the onset, intensity or duration of variations in haemodynamic parameters and application of the ointment.

Topical nifedipine's clinical applications also extended to other types of wounds, such as diabetic ulcers [48, 49]. In a case report of a 65 -year-old patient with a diabetic foot ulcer, nifedipine $10 \%$ gel was effective in healing the wound [48]. However, this was used in conjunction with other wound healing agents (phenytoin and misoprostol) [48]. Other case reports are documented of transdermal nifedipine (2\% and $8 \%$ in Poloxamer 407 Lecithin Organo (PLO) gel), applied twice daily for local vasodilation to enhance chronic ulcers healing [50]. In all these reports, no systemic adverse effects were observed during the treatment period [50].

Topical lidocaine clinical applications were investiganed in multicenter, double-blind, randomized controlled clinical trial [51].

The CLIFE-2010FV study design was provided a multicenter, double-blind, randomized controlled clinical trial with parallel group superiority of CLIFE1 topical treatment (both lidocaine and diclofenac) versus CLIFE2 topical treatment (lidocaine only) for postoperative pain therapy in benign anorectal surgery (BARS), including fistulectomy, fissurectomy and hemorrhoidectomy surgeries [51]. All adult patients met the following inclusion criteria: patients undergoing BARS hemorrhoidectomy, anal fissure (internal lateral sphincterotomy) or fistula surgery (fistulectomy) under lidocaine spinal anesthesia according to standard protocol. Eexclusion criteria were following: pregnancy, general and incomplete spinal anesthesia, intolerance to topical treatment ingredients, gastrointestinal inflammatory illness, active channel blockers and the presence of allergy.

No systemic adverse effects were observed during the treatment period. Both topical treatments were safe from the day of surgery until the seventh postoperative day. There were no recorded side effects with local treatment in all groups of patients.

Among these studies in vitro pharmacokinetics of extemporaneously compounded topical calcium channel blockers used for wounds and skin ulcers have been researched quite recently [10].

Diltiazem and nifedipine (the calcium channel blockers with the most evidence for topical use) were compounded extemporaneously with cream, gel, and ointment bases. As from previous abovementioned studies till 2019 drug release and stability information on these formulations remained scarce this project aimed to: 
(1) establish drug release profiles of compounded topical nifedipine and diltiazem in commonly used cream, gel and ointment bases using Franz diffusion cell system,

(2) determine shelf-life and beyond-use dates of products stored in white plastic and glass amber containers at room $\left(23^{\circ} \mathrm{C}\right)$, refrigerator $\left(4^{\circ} \mathrm{C}\right)$ and elevated $\left(40^{\circ} \mathrm{C}\right)$ temperatures for 90 days.

In these experiments were used drug release and diffusion systems - in vitro methods for assessing drug release and permeation by drug diffusion through a membrane [10]. They were used to determine whether a topical medication permeated through the skin to cause systemic adverse effects [52].

The Franz diffusion cell system is the most used in vitro drug release testing system for semi-solid formulations (creams, gels, and ointments) [53]. For release studies, synthetic membranes such as cellulose or silicone were used while for permeation studies, membranes that resemble the skin such as full-thickness skin, epidermal membrane, or stratum corneum were used [10].

In vitro release rates were determined from at least five sampling points (over a six-hour time frame) to plot drug release per unit area $\left(\mu \mathrm{g} / \mathrm{cm}^{2}\right)$ against the square root of time [10]. The release rate was the slope of this line, calculated using regression analysis [10]. The Franz diffusion cell system was therefore used for nifedipine release from commonly used compounding bases in pharmacy practice (Glaxal Base ${ }^{\mathrm{TM}}$, K-Y® Jelly, and Aquaphor ${ }^{\circledR}$ Healing Ointment). Methods of nifedipine analysis were validated according to ICH guidelines [54].

Nifedipine release was shown to follow Higuchi's mathematical model, as it had the highest coefficient of determination $\left(R^{2}\right)$ for most formulations [10]. Topical nifedipine $0.2 \%(\mathrm{w} / \mathrm{w})$ in Glaxal Base ${ }^{\mathrm{TM}}$ showed the highest cumulative release, followed by $2 \%$ and $10 \%$, respectively. The higher release with the lower concentration may be due to less drug resistance. Nifedipine release from Aquaphor ${ }^{\circledR}$ Healing Ointment was minimal, potentially a result of nifedipine lipophilicity, as lipophilic compounds are released minimally from lipophilic bases (such as an ointment) [10]. At $0.2 \%$, nifedipine release was highest from Glaxal Base $^{\mathrm{TM}}$. At 2 and $10 \%$, nifedipine release was highest from K-Y® Jelly, although this was only significantly different from Glaxal Base ${ }^{\mathrm{TM}}$ at $6 \mathrm{~h}$ and 1.5, $4,6 \mathrm{~h}$, respectively.

Stability studies for nifedipine in Glaxal Base $^{\mathrm{TM}}$, K-Y ${ }^{\circledR}$ Jelly, and Aquaphor ${ }^{\circledR}$ Healing Ointment were also completed using accurate and precise extraction methods and a validated stability indicating method [10]. Nifedipine potency in Glaxal $\operatorname{Base}^{\mathrm{TM}}(0.2 \% \mathrm{w} / \mathrm{w})$ was within the recommended range for 90 days (excluding day 14), in WP jars at all temperatures. The $\mathrm{pH}$ was also stable with a change of less than 1-unit $\mathrm{pH}$.

Thus, during the study establishing drug release profiles of compounded topical nifedipine and diltiazem with commonly used bases were demonstrated that Glaxal Base ${ }^{\mathrm{TM}}$ had the highest nifedipine release at the current clinically used concentration for anal fissures treatment $(0.2 \%)$, while both Glaxal Base ${ }^{\mathrm{TM}}$ and K-Y® Jelly may be appropriate choices for higher concentrations (2\%, $10 \%$ ) used for other types of wounds (e.g., diabetic ulcers). The cream and gel had the highest release and optimal stability for nifedipine and diltiazem, respectively. This study provided pharmacists with the scientific rationale for compounding bases selection and storage of topically compounded nifedipine and diltiazem products.

\section{Conclusions}

Analysis of all available studies (during last 2 decades) which were aimed to investigate pharmacokinetic characteristics of a nifedipine and lidocaine fixed combination in the form of rectal cream showed that following topical application, the active ingredients nifedipine and lidocaine are absorbed into the bloodstream in only small quantities that have no major implications for the safety of the product, and systemic absorption, if any, was incomparably lower than absorption following per os administration of the two active ingredients.

\section{References}

[1] Hua S. Physiological and pharmaceutical considerations for rectal drug formulations. Front Pharmacol. 2019;10:1196. DOI: $10.3389 /$ fphar.2019.01196

[2] Purohit TJ, Hanning SM, Wu Z. Advances in rectal drug delivery systems. Pharm Dev Technol. 2018 Dec;23(10):942-52. DOI: $10.1080 / 10837450.2018 .1484766$

[3] Lowry M. Rectal drug administration in adults: how, when, why. Nurs Times. 2016 Feb 24-Mar 1;112(8):12-4.

[4] van Hoogdalem E, de Boer AG, Breimer DD. Pharmacokinetics of rectal drug administration, Part I. Clin Pharmacokinet. 1991 Jul;21(1):11-26. DOI: 10.2165/00003088-199121010-00002 
[5] Salem AE, Mohamed EA, Elghadban HM, Abdelghani GM. Potential combination topical therapy of anal fissure: development, evaluation, and clinical study. Drug Deliv. 2018 Nov;25(1):1672-82. DOI: 10.1080/10717544.2018.1507059

[6] Guideline on clinical development of fixed combination medicinal products - Revision 2 (EMA/CHMP/158268/2017). European Medicines Agency; 2017. 12 p.

[7] Equivalence studies for the demonstration of therapeutic equivalence for locally applied, locally acting products in the gastrointestinal tract (CPMP/EWP/239/95 Rev. 1, Corr. 1). European Medicines Agency; 2019. 13 p.

[8] ICH Topic E 3. Structure and content of clinical study reports. Step 5. Note for guidance on structure and content of clinical study reports (CPMP/ICH/137/95). European Medicines Agency; 1996. 48 p.

[9] Guideline on the investigation of bioequivalence (CPMP/EWP/QWP/1401/98 Rev. 1/Corr). European Medicines Agency; 2010. 27 p.

[10] Teimouri A. Extemporaneously compounded topical calcium channelblockers for wounds and skin ulcers [MSc thesis]. Nova Scotia: Dalhousie UniversityHalifax; 2019.

[11] Carapeti EA, Kamm MA, Evans BK, Phillips RK. Topical diltiazem and bethanechol decrease anal sphincter pressure without side effects. Gut. 1999 Nov;45(5):719-22. DOI: 10.1136/gut.45.5.719

[12] Cook TA, Branding AF, Mortensen NJ. The pharmacology of the internal anal sphincter and new treatments of ano-rectal disorders. Aliment Pharmacol Ther. 2001 Jul;15(7):887-98. DOI: 10.1046/j.1365-2036.2001.00995.x

[13] Chrysos E, Xynos E, Tzovaras G, Zoras OJ, Tsiaoussis J, Vassilakis SJ. Effect of nifedipine on rectoanal motility. Dis Colon Rectum. 1996 Feb;39(2):212-6. DOI: 10.1007/BF02068078

[14] Antropoli C, Perrotti P, Rubino M, Martino A, De Stefano G, Migliore G, et al. Nifedipine for local use in conservative treatment of anal fissures: preliminary results of a multicenter study. Dis Colon Rectum. 1999 Aug;42(8):1011-5. DOI: 10.1007/BF02236693

[15] Ezri T, Susmallian S. Topical nifedipine vs. topical glyceryl trinitrate for treatment of chronic anal fissure. Dis Colon Rectum. 2003 Jun;46(6):805-8. DOI: 10.1007/s10350-004-6660-8

[16] Perrotti P, Antropoli M, Noschese G, Bartone G, De Stefano G, Pacifico F, et al. Topical nifedipine( $\left({ }^{\circledR}\right)$ for conservative treatment of acute hemorrhoidal thrombosis. Colorectal Dis. 2000 Jan;2(1):18-21. DOI: 10.1046/j.1463-1318.2000.00130.x

[17] Gough MJ, Lewis A. The conservative treatment of fissure-in-ano. Br J Surg. 1983 Mar;70(3):175-6. DOI: 10.1002/bjs.1800700312

[18] Jonas M, Neal KR, Abercrombie JF, Scholefield JH. A randomized trial of oral vs. topical diltiazem for chronic anal fissures. Dis Colon Rectum. 2001 Aug;44(8):1074-8. DOI: 10.1007/BF02234624

[19] Kujur ADS, Paul Ekka NM, Chandra S, Lal S, Malua S. Comparative study to assess the effectiveness of topical nifedipine and diltiazem in the treatment of chronic anal fissure. J Family Med Prim Care. 2020 Nov 30;9(11):5652-7. DOI: $10.4103 /$ jfmpc.jfmpc_986_20

[20] Neiger A, Herms E. The symptomatic therapy of hemorrhoids and anal eczema - a report of experiences from proctology practice. Schweiz Rundsch Med Prax. 1990 Aug 2;79(31-32):918-20.

[21] Cook TA, Brading AF, Mortensen NJ. Effects of nifedipine on anorectal smooth muscle in vitro Dis Colon Rectum. 1999 Jun;42(6):782-7. DOI: 10.1007/BF02236936

[22] Cook TA, Brading AF, Mortensen NJ. Differences in contractile properties of anorectal smooth muscle and the effects of calcium channel blockade. Br J Surg. 1999 Jan;86(1):70-5. DOI: 10.1046/j.1365-2168.1999.00998.x

[23] Perrotti P, Bove A, Antropoli C, Molino D, Antropoli M, Balzano A, et al. Topical nifedipine with lidocaine ointment vs. active control for treatment of chronic anal fissure: results of a prospective, randomized, double-blind study. Dis Colon Rectum. 2002 Nov;45(11):1468-75. DOI: 10.1007/s10350-004-6452-1

[24] Perrotti P, Antropoli C, Molino D, De Stefano G, Antropoli M. Conservative treatment of acute thrombosed external hemorrhoids with topical nifedipine. Dis Colon Rectum. 2001 Mar;44(3):405-9. DOI: 10.1007/BF02234741

[25] Nelson RL, Manuel D, Gumienny C, Spencer B, Patel K, Schmitt K, Castillo D, Bravo A, Yeboah-Sampong A. A systematic review and meta-analysis of the treatment of anal fissure. Tech Coloproctol. 2017 Aug;21(8):605-625. DOI: 10.1007/s10151-017-1664-2

[26] Perrotti P, Dominici P, Grossi E, Antropoli C, Giannotti G, Cusato M, et al. Pharmacokinetics of anorectal nifedipine and lidocaine (lignocaine) ointment following haemorrhoidectomy: an open-label, single-dose, phase IV clinical study. Clin Drug Investig. 2009;29(4):243-56. DOI: 10.2165/00044011-200929040-00003

[27] Perrotti P, Grumetto L, Barbato F, Antropoli C. Serum levels and possible haemodynamic effects following anorectal application of an ointment containing nifedipine and lignocaine: a study in healthy volunteers. Clin Drug Investig. 2006;26(8):459-67. DOI: 10.2165/00044011-200626080-00004

[28] Raemsch KD, Sommer J. Pharmacokinetics and metabolism of nifedipine. Hypertension. 1983 Jul-Aug;5(4 Pt 2):II18-24. DOI: 10.1161/01.hyp.5.4_pt_2.ii18

[29] Traube M, Hongo M, McAllister RG Jr, McCallum RW. Correlation of plasma levels of nifedipine and cardiovascular effects after sublingual dosing in normal subjects. J Clin Pharmacol. 1985 Mar;25(2):125-9. DOI: 10.1002/j.1552-4604.1985.tb02812.x 
[30] Kurosawa S, Kurosawa N, Owada E, Matsuhashi N, Ito K. Rectal administration of nifedipine: hemodynamic effects and pharmacokinetics in hypertensives. J Int Med Res. 1987 May-Jun;15(3):121-7. DOI: 10.1177/030006058701500301

[31] Kleinbloesem CH, van Harten J, de Leede LG, van Brummelen P, Breimer DD. Nifedipine kinetics and dynamics during rectal infusion to steady state with an osmotic system. Clin Pharmacol Ther. 1984 Sep;36(3):396-401. DOI: 10.1038/clpt.1984.194

[32] Covino BG. Toxicity of local anesthetic agents. Acta Anaesthesiol Belg. 1988;39(3 Suppl 2):159-64.

[33] Tucker GT, Mather LE. Clinical pharmacokinetics of local anesthetics. Clin Pharmacokinet. 1979 Jul-Aug;4(4):241-78. DOI: $10.2165 / 00003088-197904040-00001$

[34] Echizen H, Eichelbaum M. Clinical pharmacokinetics of verapamil, nifedipine and diltiazem. Clin Pharmacokinet. 1986 Nov-Dec;11(6):425-49. DOI: 10.2165/00003088-198611060-00002

[35] Covino BG. Pharmacology of local anesthetics. Br J Anaesth. 1986 Jul;58(7):701-16. DOI: 10.1093/bja/58.7.701

[36] Tonsuwannont W, Praisontarangkul OA, Manorot M, Klangwarnwong D. Pharmacokinetics of oral lidocaine and nifedipine in patients with liver cirrhosis. J Med Assoc Thai. 1996 May;79(5):309-19.

[37] Hardman JG, Limbird LE, Molinoff PB, Ruddon RW, editors. Goodman \& Gilman's the pharmacological basis of therapeutics. 9th ed. New York: McGraw-Hill; 1996. p. 1754-65.

[38] Shiau JM, Su HP, Chen HS, Hung KC, Lin SE, Tseng CC. Use of a topical anesthetic cream (EMLA) to reduce pain after hemorrhoidectomy. Reg Anesth Pain Med. 2008 Jan-Feb;33(1):30-5. DOI: 10.1016/j.rapm.2007.07.012

[39] Vickers ER, Marzbani N, Gerzina TM, McLean C, Punnia-Moorthy A, Mather L. Pharmacokinetics of EMLA cream 5\% application to oral mucosa. Anesth Prog. 1997 Winter;44(1):32-7.

[40] Leopold A, Wilson S, Weaver JS, Moursi AM. Pharmacokinetics oflidocaine delivered from a transmucosal patch in children. Anesth Prog. Summer 2002;49(3):82-7.

[41] Jensen SL. Treatment of first episodes of acute anal fissure: prospective randomised study of lignocaine ointment versus hydrocortisone ointment or warm sitz baths plus bran. Br Med J (Clin Res Ed). 1986 May 3;292(6529):1167-9. DOI: $10.1136 / \mathrm{bmj} .292 .6529 .1167$

[42] McDonald P, Driscoll AM, Nicholls RJ. The anal dilator in the conservative management of acute anal fissures. Br J Surg. 1983 Jan;70(1):25-6. DOI: 10.1002/bjs. 1800700109

[43] Havlickova B, Weyandt GH. Therapeutic management of anal eczema: an evidence-based review. Int J Clin Pract. 2014 Nov;68(11):1388-99. DOI: 10.1111/ijcp.12457

[44] Brown AC, Sumfest JM, Rozwadowski JV. Histopathology of the internal anal sphincter in chronic anal fissure. Dis Colon Rectum. 1989 Aug;32(8):680-3. DOI: 10.1007/BF02555773

[45] Benfeldt E, Serup J, Menné T. Effect of barrier perturbation on cutaneous salicylic acid penetration in human skin: in vivo pharmacokinetics using microdialysis and non-invasive quantification of barrier function. Br J Dermatol. 1999 Apr;140(4):739-48. DOI: $10.1046 /$ j.1365-2133.1999.02859.x

[46] Misra MC, Imlitemsu. Drug treatment of haemorrhoids. Drugs. 2005;65(11):1481-91. DOI: 10.2165/00003495-200565110-00003

[47] Nisar PJ, Scholefield JH. Managing haemorrhoids. BMJ. 2003 Oct 11;327(7419):847-51. DOI: 10.1136/bmj.327.7419.847

[48] Wynn T. Case report: wound care of a diabetic foot ulcer. Int J PharmCompd. 2004;8(4):265-7.

[49] Santis AK, De Freitas Z, Maria F, Ricci-Junior E, De Brito-Gitirana L, FonsecaLB, et al. Nifedipine in semi-solid formulations for topical use in peripheral vascular disease: preparation, characterization, and permeation assay. Drug Dev Ind Pharm. 2013 Jul;39(7):1098-106. DOI: 10.3109/03639045.2012.711833

[50] Torsiello MJ, Kopacki MH. Transdermal nifedipine for wound healing: case reports. Int J Pharm Compd. 2000 SepOct; $4(5): 356-8$.

[51] Linares-Gil MJ, Valls J, Hereu-Boher P, Nebot FJ, De-Ramón B, Diaz-Munió E, et al. Topical analgesia with lidocaine plus diclofenac decreases pain in benign anorectal surgery: Randomized, double-blind, and controlled clinical trial. Clin Transl Gastroenterol. 2018 Nov 23;9(11):210. DOI: 10.1038/s41424-018-0075-7

[52] Phoenix ${ }^{\mathrm{TM}}$ Dry Heat Systems [Internet]. Synersy.fr. 2021 [cited 2021 Feb 10]. Available from: http://www.synersy.fr/99310067-Rev.-04-18-Phoenix-Diffusion-Testing-Systems.pdf

[53] Thakker K, Chern W. Development and validation of in vitro release tests for semisolid dosage forms-case study. Dissolution Technologies. 2003;10(2):10-5. DOI: 10.14227/DT100203P10

[54] Validation of analytical procedures: Text and methodology Q2(R1). [Internet]. Database.ich.org. 2021 [cited 2021 Feb 10]. Available from: https://database.ich.org/sites/default/files/Q2\%28R1\%29\%20Guideline.pdf 


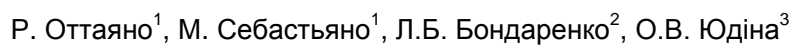

${ }^{1}$ New.Fa.Dem., S.r.I., Джульяно-ін-Кампанія, Італія

ДУ “Інститут фармакології та токсикології НАМН України”, Київ, Україна

ЗТОВ "УА "ПРО-ФАРМА", Київ, Україна

\section{ФАРМАКОКІНЕТИЧНІ ХАРАКТЕРИСТИКИ ФІКСОВАНОЇ КОМБІНАЦІЇ НІФЕДИПІНУ ТА ЛІДОКАЇНУ У ФОРМІ РЕКТАЛЬНОГО КРЕМУ: АНАЛІЗ ДАНИХ ДВОХ ДЕСЯТИЛІТЬ}

Створення фіксованих композицій лікарських засобів зі сполук із взаємодоповнювальною дією - один із найпопулярніших напрямів сучасної фармакології та фармацевтики. У разі фіксованої комбінації ніфедипіну та лідокаїну такий підхід $є$ очевидним. Наша оглядова стаття присвячена аналізу результатів клінічних і неклінічних досліджень з оцінки фрармакокінетичних характеристик цих лікарських засобів. Хоча пероральний шлях введення є найбільш зручним для введення лікарських засобів, існує низка обставин, за яких це неможливо ні з клінічної, ні з фармацевтичної точки зору. У цих випадках ректальний шлях уведення може становити практичну альтернативу та використовуватись для введення лікарських засобів як місцевої, так і системної дії. Дані досліджень останніх десятиліть показали, що ніфедипін, блокатор кальцієвих каналів, може бути ефективним щодо зменшення анального тиску в стані спокою та при лікуванні хронічної анальної тріщини й гострого тромбозного геморою. Інший компонент фіксованої комбінації лідокаїн - місцевий анестетик, який зазвичай використовується для полегшення болю при тріщинах заднього проходу та симптоматичному геморої. У комбінаціях лідокаїн і ніфедипін доповнюють один одного. Аналіз усіх доступних досліджень (протягом останніх 2-х десятиліть), спрямованих на вивчення фармакокінетичних характеристик фіксованої комбінації ніфедипіну та лідокаїну у формі ректального крему, показав, що після місцевого застосування активні інгредієнти ніфедипін і лідокаїн всмоктуються в кров лише у невеликій кількості, що не має суттєвих наслідків для безпечності продукту, а системна абсорбція, якщо така є, незрівнянно нижча, ніж абсорбція після введення двох активних інгредієнтів per os. Ключові слова: ніфедипін; лідокаїн; фіксована комбінація; фармакокінетичні характеристики.

\section{Р. Оттаяно ${ }^{1}$, М. Себастьяно ${ }^{1}$, Л.Б. Бондаренко ${ }^{2}$, А.В. Юдина}

${ }^{1}$ New.Fa.Dem., S.r.I., Джульяно-ин-Кампания, Италия

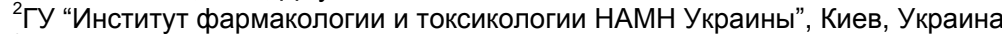

З ООО "УА "ПРО-ФАРМА", Киев, Украина

\section{ФАРМАКОКИНЕТИЧЕСКИЕ ХАРАКТЕРИСТИКИ ФИКСИРОВАННОЙ КОМБИНАЦИИ НИФЕДИПИНА И ЛИДОКАИНА В ФОРМЕ РЕКТАЛЬНОЙ КРЕМА: АНАЛИЗ ДАННЫХ ДВУХ ДЕСЯТИЛЕТИЙ}

Создание фиксированных комбинаций лекарственных средств из соединений с взаимодополняющим действием - одно из самых популярных направлений современной фармакологии и фармацевтики. В случае фриксированной комбинации нифедипина и лидокаина такой подход очевиден. Данная обзорная статья посвящена анализу результатов клинических и неклинических исследований по оценке фармакокинетических характеристик этих лекарственных средств. Хотя пероральный путь введения является наиболее удобным для введения лекарств, существует ряд обстоятельств, при которых это невозможно ни с клинической, ни с фармацевтической точки зрения. В этих случаях ректальный путь введения может представлять практическую альтернативу и может использоваться для введения лекарств как местного, так и системного действия. Данные исследований последних десятилетий показали, что нифедипин, блокатор кальциевых каналов, может быть эффективным в снижении анального давления в состоянии покоя и при лечении хронической анальной трещины и острого тромбозного геморроя. Другой компонент фиксированной комбинации лидокаин - местный анестетик, обычно используемый для облегчения боли при трещинах заднего прохода и симптоматическом геморрое. В комбинациях лидокаин и нифедипин дополняют друг друга. Анализ всех доступных исследований (за последние 2 десятилетия), направленных на изучение фармакокинетических характеристик фиксированной комбинации нифедипина и лидокаина в форме ректального крема, показал, что после местного применения активные ингредиенты нифедипина и лидокаина всасываются в кровоток только в незначительных количествах, которые не оказывают большого влияния на безопасность продукта, а системная абсорбция, если таковая имеется, оказывается несравнимо ниже, чем абсорбция после введения обоих активных ингредиентов per os.

Ключевые слова: нифедипин; лидокаин; фиксированная комбинация; фармакокинетические характеристики. 